nature

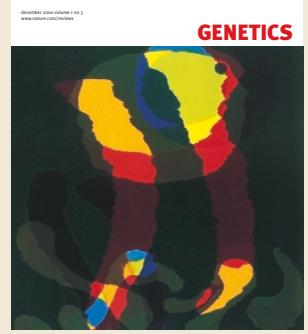

december 2000 vol. 1 no. 3

Cover art: 'Spectrumate I'

Oil on paper

by Paul Harrison

p.l.harrison@dundee.ac.uk

NEXT MONTH

Genomic imprinting

W. Reik and J. Walter

Quantitative traits in Drosophila

T. F. C. Mackay

Hox gene evolution

P. W. H. Holland and

D. E. K. Ferrier

Origin of variant genetic codes

R. D. Knight, S. J. Freeland and

L. F. Landweber

Cancer genetics and

epidemiology

J. D. Potter

Ethics of stem cell research

J. A. Robertson

E-MAILALERTS

Get monthly alerts of the content

of this journal - sent FREE to

your inbox - by registering on

our online site today!

www.nature.com/reviews

CONTINUOUS PUBLICATION

Nature Reviews Genetics

operates a continuous

publication service fo

authors and readers.

Why wait for your print copy?

Simply go to

www.nature.com/reviews

/genetics to view the most

topical reviews in genetics.

DISCOUNT SUBSCRIPTIONS

STUDENTS! Did you know that

an online-only subscription to

Nature Reviews Genetics costs

just $\mathrm{f}_{31}$ (US\$50)? Combined

print and online subscriptions

are also available for personal

and student subscribers - visit

www.nature.com/reviews/

genetics to subscribe.

SITE LICENCES

Available from January 2001

for more information on site

licences and institutional online

access, contact

s.archer@nature.com or call

$+44(0) 2078434626$

nature REVIEWS
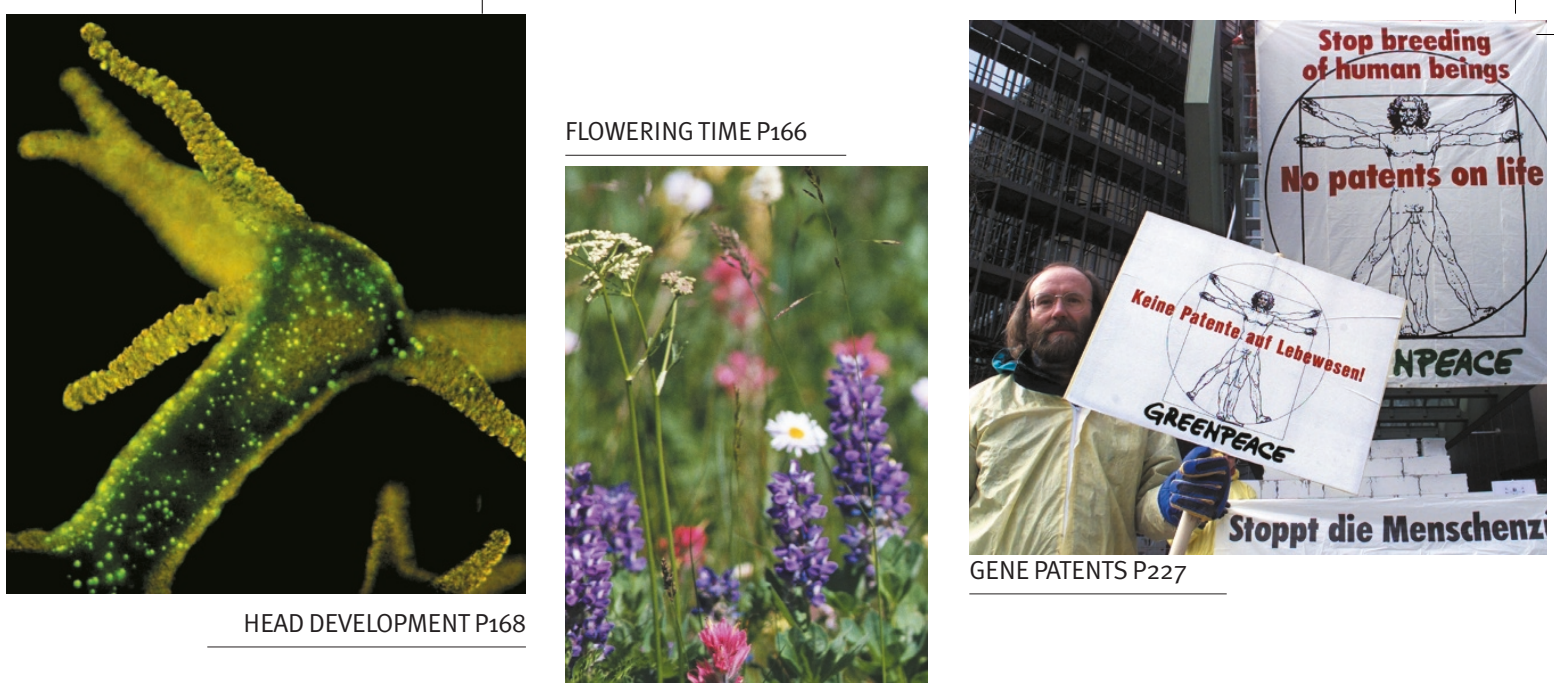

HEAD DEVELOPMENT P168

GENE PATENTS P227

\title{
PERSPECTIVES
}

EVOLUTION

163 Same rates for neighbours

IN BRIEF

164 DNA recombination / Gene expression I

Technology I Disease model

POPULATION GENETICS

164 Founding populations: Colombian blend? BIOINFORMATICS

165 Mining gene expression data

WEB WATCH

165 Homophila

WEB WATCH

166 Genetic testing 1, 2, 3

PLANT GENETICS

166 If winter comes, will flowers follow?

MALARIA

167 Resisting drugs

HUMAN GENETICS

167 New light on night blindness

DEVELOPMENTAL BIOLOGY

168 Headless Hydra get Heady

CANCER

168 The trouble with smoking

SEX DETERMINATION

169 It's a guy thing

IN BRIEF

169 Gene expression I Human genetics | Developmental biology

\section{SCIENCE AND SOCIETY}

227 Patenting human genetic material: refocusing the debate

Timothy Caulfield, E. Richard Gold and Mildred K. Cho

Ethical debates on the appropriateness of patenting human genetic material have had little effect on the granting of these patents. Focusing the debate on the practical implications of genetic patents could improve future patent practices.

\section{TIMELINE}

231 The origins of bioinformatics Joel B. Hagen

In the 1960s, a decade before DNA sequencing, biologists used the accumulating data from protein sequences to develop the computing skills necessary for modern bioinformatics.

\section{TIMELINE}

236 Genetic disease since 1945

\section{Susan Lindee}

Genetics is now seen as an important factor in all human disease. But in the 1940s medical genetics didn't really exist. How did this dramatic transformation take place?

NATUREVIEW

243 Reviews and comment from Nature journals 


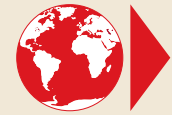

december 2000 vol. 1 no. 3

This icon directs the reader to additional useful material available only on our website

WEB ONLY MATERIAL

LINKS

Most articles contain links within, and at the end of, the text. Links to useful resources include video presentations, the Encyclopedia of Life Sciences (www.els.net), relevant databases and further reading material. These are listed in the Links box at the end of Reviews and Perspectives articles.

ANIMATION

Some of our figures are animated online. Take a look at Figure 3 in

the article by De Robertis, Larraín, Oelgeschläger and Wessely.

SLIDE SHOWS

The 'slide show' feature gives you a visual summary of each review article's most important concepts. Figures can be downloaded for use in presentations.

\section{EXECUTIVE SUMMARIES}

Each review provides an overview, offering a useful summary of the main topics covered in the article.

BIOGRAPHIES

Short author biographies are

provided online.

SUBSCRIPTION INFORMATION (Nature Reviews Genetics) (ISSN 1471-0056) is published monthly by Nature Publishing London $\mathrm{N}_{1} \mathrm{gXW}, \mathrm{UK}$ ). Editorial Office:

Porters South, 4-6 Crinan Street, London N1 9 XW, UK. Tel: +44 (o) 207843 3601. Fax: +44 (o) 2078433629 . E-mail: NatureReviews@nature.com North American Advertising: Nature Reviews GYetics, 345 Park Avenue South, New York Fax: +1(212) 696-9006. European Advertising: Nature Reviews Genetics, Porters South, 4-6Crinan Street, London N1 9XW, UK. Tel: +44 (0) 207843 4960. Fax: +44 (o) 2078434996 New subscriptions/renewals/changes of address/back issues and all other customer Americas: Nature Reviews Genetics. Subscription Dept, P.O. Box 5161, Brentwood, TN 37024-5161, USA. Tel: +1(800) 524-2688 (in the US) +1(615) 850-5315 (outside the US) Fax: +1(615) 377-0525 E-mail: subscriptions@natureny.com UK/Euro/ROW (excluding Japan): Dapt, Brunel Road, Basingstoke, Hants. RG21 6XS, UK. Tel: +44 (o) 1256302820 Fax: +44 (0) 1256812358 E-mail: subscriptions@nature.com lapan: Contact Japan Publications Trading Co. Ltd., 2-1 Sarugaku-cho 1 chome Chiyoda-ku, Tokyo 101, Japan, Annual subscription rates: US/Canada (institutional/corporate), \$129 (individual making personal payment) Canadian prices include $7 \%$ GST; UK/Europe/ROW (excluding Japan) $f_{565 / \$ 904}$ (institutional/corporate), f82/\$129 (individual making personal payment), $\{75 / \$ 119$ (student \& postdoc); Japan. Contact Japan Publications Trading Chiyoda-ku Tokyo 101, 1 pan phone +81(03) 292-3755. POSTMASTER: Send address changes to Nature Reviews Genetics, Subscriptions Department, Brunel Road, Basingstoke, Hants. RG21 6XS, UK or Nature Reviews Genelics, Subscriptions Department PO

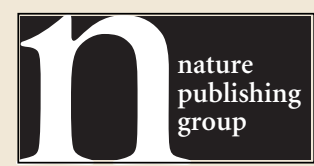

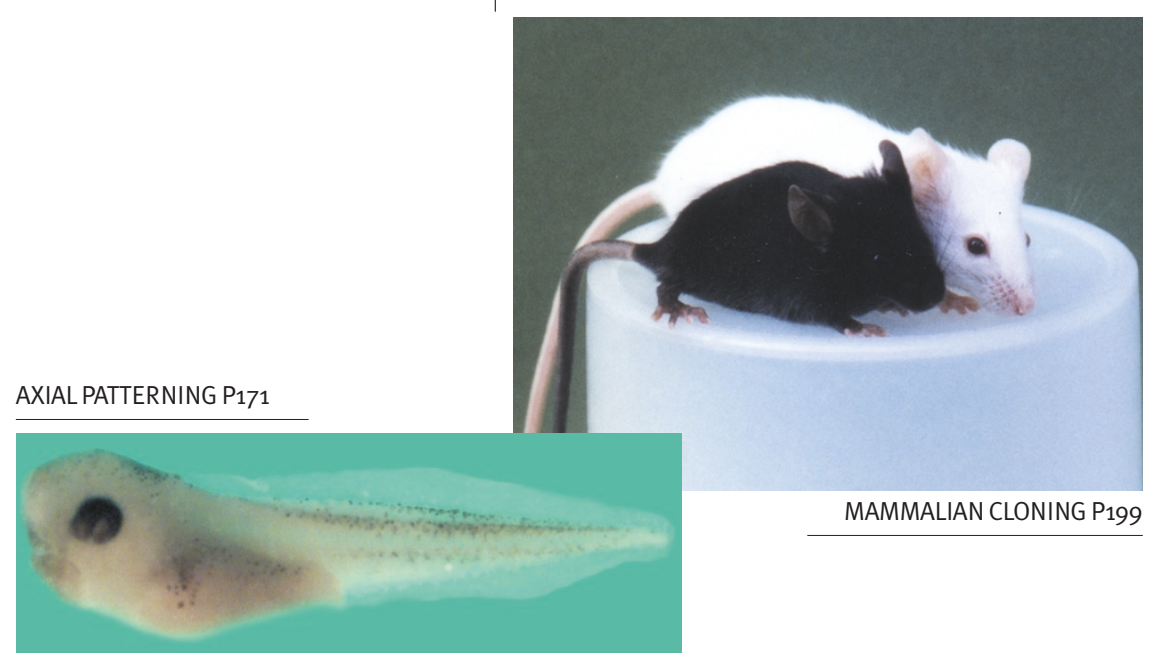

REVIEWS

171 The establishment of Spemann's organizer and patterning of the vertebrate embryo

E. M. De Robertis, J. Larraín, M. Oelgeschläger and O. Wessely

Many different types of molecule can function as dorsal determinants in Xenopus.

This puzzling observation can be explained by the fact that multiple proteins participate sequentially in a common pathway to pattern the dorsal-ventral axis.

182 Use of population isolates for mapping complex traits

Leena Peltonen, Aarno Palotie and Kenneth Lange

Isolated populations offer several advantages for the study of monogenic human disease, such as reduced genetic and environmental heterogeneity compared with outbred populations. But will these advantages apply in the study of complex disease?

191 Genome gymnastics: unique modes of DNA evolution and processing in ciliates

David M. Prescott

The plasticity of the genome is taken to extremes in ciliates. Functional genes have to be stitched together from fragments that are often in a scrambled order. These properties have been important in ciliate evolution.

199 Mammalian cloning: advances and limitations

Davor Solter

Despite recent progress, cloning mammals remains a hit-and-miss procedure. A better understanding of the events that accompany nuclear transfer, such as genome reprogramming, should help overcome barriers to improved cloning efficiency.

208 Iron homeostasis: insights from genetics and animal models

Nancy C. Andrews

Although iron is essential for many vital biological processes, excessive iron is toxic to many organisms. Studies of genetic disease and animal models have revealed much about how different cells maintain iron homeostasis.

\section{Using Drosophila as a model insect}

David Schneider

Insect-borne diseases are a health and agricultural burden. Drosophila can be used as a model insect, providing a tractable system to investigate pesticide-insect interactions and the biology of pathogenic vectors. 


\section{nature REVIEWS}

NATURE REVIEWS GENETICS

\section{EDITORIAL OFFICES}

LONDON NatureReviews@nature.com Porters South,

4 Crinan Street, London N1 9XW Tel: +44 (0) 207843 3601;

Fax: +44 (0) 2078433629

EDITOR: Mark Patterson

ASSOCIATE EDITORS: Jane Alfred, Tanita Casci

ART EDITOR: Radha Clelland

SENIOR ART EDITOR: Nicola Barker

EDITORIAL PRODUCTION: Judith Shadwell, Peter Kirkpatrick,

Alison Schuldt

OFFICE MANAGER: Luisa Estanislao

WORLD WIDE WEB: http://www.nature.com/reviews

DIRECTOR OF ELECTRONIC PUBLISHING SERVICES: Don FiCK

ELECTRONIC PRODUCTION MANAGER, US: Joe Landolfi

ELECTRONIC PRODUCTION MANAGER, UK: James Porteous

ELECTRONIC PRODUCTION COORDINATOR: Nick Allin

\section{MANAGEMENT OFFICES}

LONDON nature@nature.com Porters South, 4 Crinan Street, London N1 gXW Tel: +44 (0) 207833 4000;

Fax: +44 (0) $2078434596 / 7$

MANAGING DIRECTOR: Annette Thomas

ASSOCIATE DIRECTORS: Jenny Henderson, Tony Rudland

EDITOR-IN-CHIEF, NATURE PUBLICATIONS: Philip Campbell

EUROPEAN SALES MANAGER: Simon Horner

CLASSIFIED ADVERTISING MANAGER: Fabien Savenay

GROUP MARKETING MANAGER: Michelle Tempest-Mitchell

SENIOR MARKETING EXECUTIVE: Philippa Rego

PRODUCTION MANAGER: Yvonne Strong

PRODUCTION CONTROLLER: Jeff Bird

ELECTRONIC PRODUCTION ASSISTANT: Jason Rayment

NEW YORK nature@natureny.com 345 Park Avenue South,

10th Floor, New York, NY 10010-1707

Tel: +1 212726 9200; Fax: +1 2126969006

VICE PRESIDENT SALES: Marion Delaney

DISPLAY ADVERTISING DIRECTOR: Bill Moran

CLASSIFIED ADVERTISING MANAGER: Ben Crow

VICE PRESIDENT MARKETING: Phillip LoFaso

NEW PRODUCT DEVELOPMENT MANAGER : Mark Tesorier

ASSISTANT NEW PRODUCT DEVELOPMENT MANAGER:

David Mekeel

CIRCULATION MANAGER: Richard Chung

TOKYO nature@naturejpn.com

Shin-Mitsuke Building (3F), 3-6 Ichigaya Tamachi, Shinjuku-ku,

Tokyo 162 Tel: +81332678751 ; Fax: +81 332678746

ASIA-PACIFIC PUBLISHING DIRECTOR: David Swinbanks

MANAGER: Koichi Nakamura

MANAG ADVERTISEMENT MANAGER: Kate Cowa

JAPAN ADVERTISEMENT MANAGER: Kate Cowan
MARKETING: Rinoko Asami, Michael Thompson, Danny Choo

MARKETNG: RinOKO Asami, Micha

CIRCULATION: Karin Shigenobu

AUSTRALIA aabbott@macmillan.com.au

Macmillan Magazines, 84 Dodds Street, PO Box 1346,

South Melbourne, Victoria 3205

Tel: +61 39645 9444; Fax: +61 39645722

MARKETING MANAGER: Annette Abbott

DISPLAY ADVERTISING

North America display@natureny.com

NEW YORK: North America Head Office Tel +1 2127269200

CHICAGO: Didier \& Broderick, Inc. Tel +1 8474984520 ,

Fax +18474985911

US WEST COAST, SOUTHWEST AND WEST CANADA:

Jim Secretario Tel +1 8002299758

EAST COAST AND EAST CANADA: Perla Gomez Tel +1 2127269258

EUROPE/REST OF WORLD display@nature.com

SALES EXECUTIVES: Claire Hines, Nike Baruwa, Ian Bailey,

James Buckley

SALES CO-OPDINATOR: Lynette Turner

Tel +44 (o) 207843 4967, Fax +44 (o) 2078434749

FRANCE, BENELUX AND SPAIN: Murieal Chaizmartin

Tel +331438742 17, Fax +33143874215

SWITERLAND: Verena Loewentha

Tel +4152761 3030, Fax +41527613200

SCANDINAVIA: Nike Baruwa

Tel +44 (o) 207843 4960, Fax +44 (o) 2078434996

SOUTHERN GERMANY, AUSTRIA AND ITALY: Sabine Hugi-Fürs

Tel +41 527613386 , Fax +41 527613419

NORTHERN GERMANY: Gerard Preston Tel +49 8954 9057-15,

Fax +49 8954 9057-20

JAPAN: nature@naturejpn.com

Nature Japan KK Tel +81 33267 8751, Fax +8133267 8746

Original design by Jane Walker

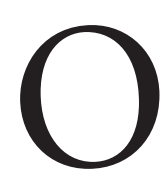

ver the past 15 years, geneticists have identified the genes for hundreds of monogenic diseases and the search is far from over. The recently reported identification of a gene for X-linked night blindness is discussed in this month's Highlights, and new insights into monogenic disorders of iron metabolism are reviewed by Nancy Andrews. But, increasingly, geneticists are shifting their attention from rare monogenic diseases to common multifactorial disorders.

There is considerable debate about how best to study multifactorial disease, and Leena Peltonen and colleagues review the strengths and weaknesses of using isolated populations for such studies. But whatever the strategy used, the prevailing concept of disease is that genetics always has a part to play. How has genetics come to occupy this central position in our perception of disease? Answers to this question are discussed in a historical analysis of the origins of medical genetics by Susan Lindee.

The origins of another discipline - bioinformatics are also considered in a Timeline article this month. Like disease genetics, bioinformatics has risen to prominence relatively recently, but Joel Hagen traces its roots back to the pioneering era of protein-sequence and -structure determination. Looking to the present, Highlights include new bioinformatic approaches to analysing microarray data, and an Internet resource for finding fly homologues of human disease genes. The fly's popularity as a model for studying human disease is increasing, but — as David Schneider reminds us in his review of Drosophila as a model for insect-borne diseases - Drosophila is more than a little person with wings.
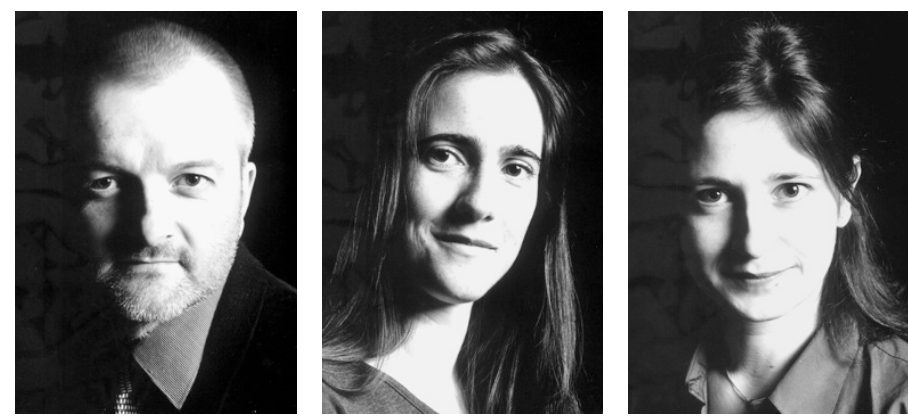

Editor

Mark Patterson PhD

Associate Editors

Jane Alfred PhD

Tanita Casci PhD 